Article

\title{
Using Mobile Device Data to Track the Effects of the COVID-19 Pandemic on Spatiotemporal Patterns of National Park Visitation
}

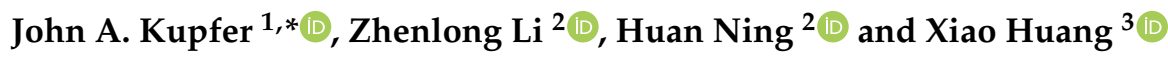 \\ 1 Department of Geography, University of South Carolina, Columbia, SC 29208, USA \\ 2 Geoinformation and Big Data Research Laboratory, Department of Geography, University of South Carolina, \\ Columbia, SC 29208, USA; zhenlong@mailbox.sc.edu (Z.L.); hning@email.sc.edu (H.N.) \\ 3 Department of Geosciences, University of Arkansas, Fayetteville, AR 72701, USA; xh010@uark.edu \\ * Correspondence: kupfer@mailbox.sc.edu
}

Citation: Kupfer, J.A.; Li, Z.; Ning, H.; Huang, X. Using Mobile Device Data to Track the Effects of the COVID-19 Pandemic on

Spatiotemporal Patterns of National Park Visitation. Sustainability 2021, 13, 9366. https://doi.org/10.3390/ su13169366

Academic Editor: Jean-Claude Thill

Received: 7 July 2021

Accepted: 15 August 2021

Published: 20 August 2021

Publisher's Note: MDPI stays neutral with regard to jurisdictional claims in published maps and institutional affiliations.

\begin{abstract}
Effective quantification of visitation is important for understanding many impacts of the COVID-19 pandemic on national parks and other protected areas. In this study, we mapped and analyzed the spatiotemporal patterns of visitation for six national parks in the western U.S., taking advantage of large mobility records sampled from mobile devices and released by SafeGraph as part of their Social Distancing Metric dataset. Based on comparisons with visitation statistics released by the U.S. National Park Service, our results confirmed that mobility records from digital devices can effectively capture park visitation patterns but with much finer spatiotemporal granularity. In general, triggers of visitation changes corresponded well with the parks' management responses to COVID-19, with all six parks showing dramatic decreases in the number of visitors (compared to 2019) beginning in March 2020 and continuing through April and May. As restrictions were eased to promote access to the parks and the benefits associated with outdoor recreation, visitation in 2020 approached or even passed that from 2019 by late summer or early autumn at most of the parks. The results also revealed that parks initially saw the greatest increases in visitation after reopening originating from nearby states, with visitorship coming from a broader range of states as time passed. Our study highlights the capability of mobility data for providing spatiotemporally explicit knowledge of place visitation.
\end{abstract}

Keywords: human mobility; mobile device data; park visitation; COVID-19; protected areas

\section{Introduction}

The COVID-19 pandemic caused by SARS-CoV-2 had profound effects on national parks and other protected areas around the world [1]. Lockdown regulations, park closures, and reduced visitor services severely affected visitation, tourism revenue and economies in nearby communities, and even local stakeholder engagement [2,3]. Conservation and management activities were influenced in complex ways that went beyond the day-to-day management of protected areas as research projects, training, and networking activities were disrupted [4]. While the news and social media provided accounts of wildlife returning to closed parks [5], protected areas were vulnerable to increases in a range of illegal activities and threats to important biological and non-biological resources [6,7]. Because previous work has demonstrated the mental and physical benefits of immersion in nature [8], park closures and restrictions also likely had impacts on human health and well-being [9].

The impacts of COVID-19 on specific protected areas and the responses of public land managers varied globally [10], but many of the issues identified above were relevant to public lands in the United States (U.S.), including those managed by the U.S. National Park Service (NPS) [11]. The core mission of the NPS, as defined by the Organic Act of 1916, is providing for the enjoyment of park scenery, natural and historic objects, and wildlife in a manner that will leave them unimpaired for the enjoyment of future generations. The 
units of the national park system offer an array of opportunities for recreation and education, with park visitation regularly exceeding 300 million annually. National park visitor spending, in turn, contributed $\$ 41.7$ billion to the U.S. economy in 2019 and supported 340,500 jobs [12]. Visitor spending is often particularly important for economies in nearby gateway communities, and fees and revenues collected by the NPS are used to enhance visitor experiences. The value of national park visitation goes beyond its economic impact, however, as parks connect Americans to their nation's history and heritage and serve as gateways to the outdoors, providing sources of inspiration and personal renewal.

COVID-19 has presented both challenges to and new opportunities for the ways in which the NPS meets its fundamental mission. In the earliest stages of the pandemic, concerns over the spread of the virus and the safety of visitors and NPS personnel led to widespread closures and restrictions. When feasible, a number of parks with large outdoor spaces remained at least partially accessible to the public or eased some restrictions fairly quickly as outdoor recreational experiences came to be seen as a refuge from the pandemic. As NPS Deputy Director Shawn Benge stated, "This past year has reminded us how important national parks and public lands are to overall well-being. Throughout the country, national parks provided close-to-home opportunities for people to spend much needed time outdoors for their physical and psychological health" [13]. Even though national park visitation dropped to 237 million in 2020, a 27.6\% decrease from 2019, some parks experienced record crowds later in the summer and autumn as reopened trails, overlooks, and open spaces provided opportunities for visitors to 'recreate responsibly' [14].

While U.S. national parks offer valuable opportunities for examining the impacts of the COVID-19 pandemic on protected areas, effectively doing so requires pertinent and timely information on multiple aspects of park visitation, including the effects of management actions on visitation numbers. The number of park visitors is typically approximated using proxies such as automatic traffic counters, ferry tickets, shuttle bus riders, aerial photographs, and manual counts. Additional information, such as visitor origin, within-park movements, or length of stay, comes from more intensive onsite surveys. As a result, obtaining up-to-date information about how people use and visit natural areas by traditional means may be laborious, time-consuming, and costly [15]. Further, some aspects of park visitation are inherently spatial and thus require analyses that incorporate spatial components [16], something that traditional methods may fail to do in a timely or effective manner, especially during a pandemic.

Approaches that exploit large quantities of data generated continuously by mobile devices can complement traditional methods used for quantifying park visitation [15,17-20]. For example, weekly user counts from Flickr, Instagram, and Twitter were coupled with ancillary data to predict visitor numbers for 42 recreation sites in northern New Mexico and western Washington [17]. In another case, geolocated social media was used as a rapid indicator of visitation and park access for more than 2000 parks in New York City [21]. After filtering out unique social media users who visited parks using historical posts, the authors modeled visitation patterns based on users' daily check-in frequencies, park characteristics, neighborhood-level accessibility, and demographics. Doing so allowed them to identify positive (e.g., access to public transportation) and negative (e.g., minority race and ethnicity) factors to the social media activity in parks. Data gleaned through social media thus provided critical information for thousands of parks, which would have been infeasible using field surveys alone.

The availability of publicly-accessible APIs (application programming interfaces) and off-the-shelf data products similarly offers promise for researchers, managers, and policy makers interested in studying park visitation but wishing to avoid primary data collection, aggregation, and management. Tencent, a social media company whose applications reach $70 \%$ of China's population (including $90 \%$ in metropolitan areas), provides public APIs to query its Tencent User Density database, which was successfully used to investigate factors affecting 'mini-park' visitation in Yancheng, China [22]. SafeGraph provides Point of Interest (POI) data that is useful for understanding spatial and temporal visitation 
patterns based on anonymized cellphone location. Their data was used to analyze daily and monthly visitation numbers in three major Florida cities and explore the effects of Hurricane Irma on daily visitation patterns in three POI categories in Miami [23]. Big data from such sources provides a means for examining place visitation patterns at large or small geographic scales in the long term or short term (annually to hourly).

Here, we examined changes in visitation patterns at six prominent U.S. national parks in response to the COVID-19 pandemic using a novel approach based on data collected anonymously from mobile devices and provided as part of SafeGraph's Social Distancing Metric dataset. Our analyses involved three steps designed to (1) clarify temporal and spatial patterns of park visitation, and (2) assess (and, if warranted, highlight) the usefulness of SafeGraph data for comparable studies. We first correlated monthly visitation data extracted from the SafeGraph dataset with data obtained from the NPS to evaluate whether the former could effectively capture patterns of park visitation. We then used the SafeGraph data to explore the correspondence between management actions taken in response to COVID-19 and patterns of park visitation. In doing so, we took advantage of the daily resolution of SafeGraph data to illustrate the effects of park closures and reopenings on visitation. Finally, we computed and mapped spatial patterns of visitor flows to examine how the pandemic impacted not just the number of visitors, but also their origins. Once again, these analyses highlighted the ability of mobile device data to provide information not readily available from standard NPS visitation data-in this case, the spatial component of visitation changes in response to COVID-19 and a park's daily visitation trend over a protracted time period using the cellphone-based SafeGraph data.

\section{Materials and Methods}

\subsection{Study Areas}

We analyzed visitation characteristics for six national parks in the western U.S.: Glacier NP, Grand Canyon NP, Rocky Mountain NP. Yellowstone NP, Yosemite NP, and Zion NP (Figure 1). These parks were selected for several reasons. First, previous work has shown that social media data tend to better approximate visitation in more heavily visited parks [15], and these parks are among the most visited units in the national park system, with average recreational visitors exceeding roughly 3 million annually from 2015-2019

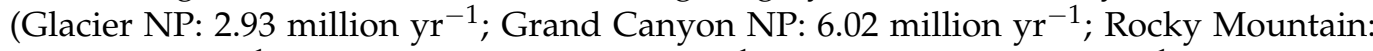
4.47 million $\mathrm{yr}^{-1}$; Yosemite NP: 4.39 million $\mathrm{yr}^{-1}$; Zion NP: 4.25 million $\mathrm{yr}^{-1}$; Yellowstone NP: 4.12 million $\mathrm{yr}^{-1}$ ). Second, visitation at all six parks is heavily oriented toward outdoor recreation and activities. Their selection is thus consistent with the primary focus of this research. Finally, these six parks are among the most iconic units in the national park system, drawing visitors from across the country and around the globe. Consequently, they provide an opportunity for examining the effects of park closures and restrictions on visitation patterns at a range of spatial scales.

For each park, we created timelines of park restrictions, closures, and reopenings related to COVID-19 based on individual park press-releases and information from the National Park Service Visitor Use Statistics (NPS VUS) website [24]. These management actions ranged from partial closures and reopenings (e.g., actions associated with one or more entrances, campgrounds, lodging facilities, or trails) to closures or reopenings of all park facilities (Table 1). Another date of note is 13 March 2020, when President Donald Trump declared a national emergency over the outbreak of COVID-19, just two days after the World Health Organization declared the global spread of COVID-19 a pandemic. 
Table 1. Timeline of restrictions, closures, and reopenings related to COVID-19 for Glacier, Grand Canyon, Rocky Mountain, Yellowstone, Yosemite, and Zion National Parks. Closures related to other factors that could significantly affect visitation numbers are also indicated.

\begin{tabular}{|c|c|c|c|c|c|c|}
\hline & Glacier NP & $\begin{array}{c}\text { Grand } \\
\text { Canyon NP }\end{array}$ & $\begin{array}{c}\text { Rocky } \\
\text { Mountain NP }\end{array}$ & Yellowstone NP & Yosemite NP & Zion NP \\
\hline $\begin{array}{l}\text { March } \\
2020\end{array}$ & $\begin{array}{l}\text { Park closed to } \\
\text { visitors due to } \\
\text { COVID-19 } \\
\text { (28 March). }\end{array}$ & $\begin{array}{c}\text { Concessioners close } \\
\text { due to COVID (late } \\
\text { March). Camping } \\
\text { permits, access to } \\
\text { some trails } \\
\text { restricted. }\end{array}$ & $\begin{array}{l}\text { Park closed to visitors } \\
\text { due to COVID-19 } \\
\text { (20 March). }\end{array}$ & $\begin{array}{l}\text { No closures } \\
\text { reported. }\end{array}$ & $\begin{array}{l}\text { Park closed to visitors } \\
\text { due to COVID-19 (20 } \\
\text { March). Lodging (17 } \\
\text { March), campgrounds } \\
\text { (19 March) closed. }\end{array}$ & $\begin{array}{c}\text { Shuttles } \\
\text { discontinued (17 } \\
\text { March); Zion Lodge } \\
\text { closes (20 March); } \\
\text { Campgrounds close } \\
\text { (27 March). }\end{array}$ \\
\hline $\begin{array}{l}\text { April } \\
2020\end{array}$ & $\begin{array}{l}\text { Park closed to } \\
\text { visitation due to } \\
\text { COVID-19. }\end{array}$ & $\begin{array}{l}\text { Park closed to } \\
\text { visitation due to } \\
\text { COVID-19 (1 April). }\end{array}$ & $\begin{array}{l}\text { Park closed to visitation } \\
\text { due to COVID-19. }\end{array}$ & $\begin{array}{l}\text { Park closed to } \\
\text { visitation due to } \\
\text { COVID-19 } \\
\text { (1 April). }\end{array}$ & $\begin{array}{l}\text { Park closed to visitation } \\
\text { due to COVID-19. }\end{array}$ & $\begin{array}{l}\text { Park closed to } \\
\text { visitation due to } \\
\text { COVID-19. }\end{array}$ \\
\hline $\begin{array}{l}\text { May } \\
2020\end{array}$ & $\begin{array}{l}\text { Park closed to } \\
\text { visitation due to } \\
\text { COVID-19. }\end{array}$ & $\begin{array}{l}\text { Park opens with } \\
\text { limited access } \\
\text { through South } \\
\text { Entrance Station } \\
\text { only. (13 May). }\end{array}$ & $\begin{array}{l}\text { Park begins phased } \\
\text { reopening ( } 27 \text { May). }\end{array}$ & $\begin{array}{l}\text { South and East } \\
\text { entrances open (18 } \\
\text { May); other } \\
\text { entrances } \\
\text { remain closed. }\end{array}$ & $\begin{array}{l}\text { Park closed to visitation } \\
\text { due to COVID- } 19 .\end{array}$ & $\begin{array}{l}\text { Entrance stations } \\
\text { closed. Soft } \\
\text { reopening of Zion } \\
\text { Lodge } \\
\text { (21 May). }\end{array}$ \\
\hline $\begin{array}{l}\text { June } \\
2020\end{array}$ & $\begin{array}{l}\text { West park entrances } \\
\text { reopen (June 8). } \\
\text { East entrances } \\
\text { remain closed. }\end{array}$ & $\begin{array}{l}\text { North Rim opens } \\
\text { for } 2 \text { weeks. }\end{array}$ & $\begin{array}{l}\text { Park implements a timed } \\
\text { entry system to manage } \\
\text { numbers and flow of } \\
\text { vehicles } \\
\text { (4 June). }\end{array}$ & $\begin{array}{l}\text { All entrances open } \\
\text { (1 June). }\end{array}$ & $\begin{array}{l}\text { Park reopens with } \\
\text { reservation only access } \\
\text { (11 June). Lodging and } \\
\text { camping extremely } \\
\text { limited. }\end{array}$ & $\begin{array}{l}\text { Park is open, } \\
\text { but some } \\
\text { campgrounds and } \\
\text { park areas remain } \\
\text { closed. }\end{array}$ \\
\hline $\begin{array}{l}\text { July } \\
2020\end{array}$ & $\begin{array}{l}\text { Park is open, but } \\
\text { with east entrances } \\
\text { closed. }\end{array}$ & Park is open. & $\begin{array}{l}\text { Timed entry system } \\
\text { continues. }\end{array}$ & All entrances open. & $\begin{array}{l}\text { Park open but with } \\
\text { reduced entry and some } \\
\text { closures/restricted } \\
\text { capacities for lodging, } \\
\text { campgrounds. }\end{array}$ & $\begin{array}{l}\text { Park open but some } \\
\text { campgrounds and } \\
\text { park areas remain } \\
\text { closed. }\end{array}$ \\
\hline $\begin{array}{l}\text { August } \\
2020\end{array}$ & $\begin{array}{l}\text { Park is open, but } \\
\text { with east entrances } \\
\text { closed. }\end{array}$ & Park is open. & $\begin{array}{l}\text { Timed entry system } \\
\text { continues. }\end{array}$ & All entrances open. & $\begin{array}{c}\text { Most park areas open. } \\
\text { Mariposa Grove is closed } \\
\text { briefly due to the Creek } \\
\text { Fire. }\end{array}$ & $\begin{array}{l}\text { Additional } \\
\text { campground } \\
\text { reopenings } \\
\text { (mid-August). } \\
\text { Commercial } \\
\text { shuttles } \\
\text { operating. }\end{array}$ \\
\hline $\begin{array}{l}\text { September } \\
2020\end{array}$ & $\begin{array}{l}\text { Park is open, but } \\
\text { with east entrances } \\
\text { closed. }\end{array}$ & Park is open. & $\begin{array}{l}\text { Timed entry system } \\
\text { continues. }\end{array}$ & All entrances open. & $\begin{array}{l}\text { Park closed due to the } \\
\text { Creek Fire } \\
\text { (18-24 September). }\end{array}$ & Park is open. \\
\hline $\begin{array}{l}\text { October } \\
2020\end{array}$ & $\begin{array}{l}\text { Park is open, but } \\
\text { with east entrances } \\
\text { closed. }\end{array}$ & Park is open. & $\begin{array}{c}\text { Timed entry system ends } \\
\text { (13 October). Park closes } \\
\text { due to wildfire } \\
\text { (21 October-5 November). }\end{array}$ & All entrances open. & Park is open. & Park is open. \\
\hline $\begin{array}{l}\text { November } \\
2020\end{array}$ & $\begin{array}{l}\text { Park is open, but } \\
\text { with east entrances } \\
\text { closed. }\end{array}$ & Park is open. & $\begin{array}{l}\text { Localized closures } \\
\text { continue due to wildfire } \\
\text { and weather. }\end{array}$ & Park is open. & Park is open. & Park is open. \\
\hline $\begin{array}{l}\text { December } \\
2020\end{array}$ & $\begin{array}{l}\text { Park is open, but } \\
\text { with east entrances } \\
\text { closed. }\end{array}$ & Park is open. & $\begin{array}{l}\text { Localized closures } \\
\text { continue due to wildfire } \\
\text { and weather. }\end{array}$ & Park is open. & $\begin{array}{c}\text { Park switches to day use } \\
\text { only } \\
\text { (7 December). }\end{array}$ & Park is open. \\
\hline
\end{tabular}
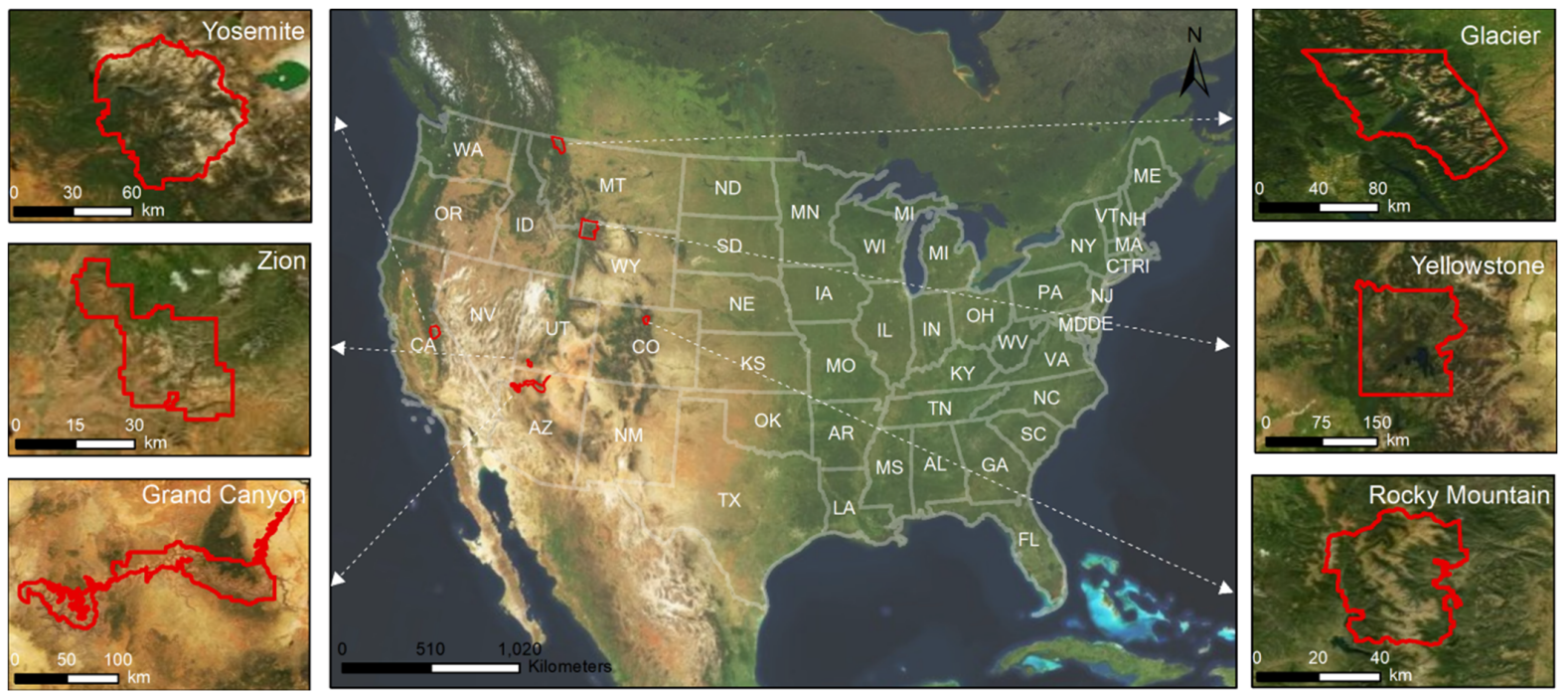

Figure 1. Locations and boundaries of the six national parks examined in this study. 


\subsection{Visitation Data}

To quantify visitation patterns for the six national parks examined in this study, we acquired visitation data for 2019 and 2020 from two sources: (1) the NPS VUS webpage [24], and (2) the SafeGraph foot traffic dataset. NPS statistics, which are provided as monthly summaries, are determined using a range of methods and proxies, including inductive loop traffic counters, pneumatic tube traffic counters, remote sensor traffic counters, and counts of visitors arriving via buses and other conveyances. Methods used to derive these estimates for individual parks can be found through the 'Visitor Use Counting Procedures' links for each park at the NPS VUS webpage.

SafeGraph (safegraph.com, accessed on 16 August 2021) is a company that provides foot traffic data collected anonymously from mobile devices such as cellphones. We specifically used SafeGraph's Social Distancing Metric data, which are based on an aggregated, anonymized, privacy-safe summary of foot traffic to 6 million POIs in North America, including national parks. These data were available at a daily timestep, making it easy to conduct daily comparisons between years while allowing for aggregation to a monthly timestep for comparisons with NPS data.

The Social Distancing Metric data include the device's 'home' location in census block groups and record daily flows between census block groups [25]. We extracted daily origin-destination (OD) flows at the census block group level from the Social Distancing Metric data using the ODT flow system [26]. Specifically, the Social Distancing Metric data contains 23 fields, three of which (origin_census_block_group, destination_cbgs, and date_range_start) were used to derive the OD flows. The origin_census_block_group refers to the unique 12-digit Federal Information Processing Standards (FIPS) code for the census block group while the destination_cbgs contains information on "the number of devices with a home in census_block_group that stopped in the given destination census block group for $>1$ min during the time period" [25].

Using these three fields, we generated an OD flow table that recorded the number of devices from an original block group to destination block groups on a daily basis in the U.S. The OD flow table contained over 6 billion $(6,144,802,397)$ daily flows for 2019 and over 4.9 billion $(4,963,893,674)$ daily flows for 2020 . Based on the OD flow table, we extracted daily flow data in 2019 and 2020 for each of the six national parks according to census block group IDs. All data were stored in a distributed file system (HDFS), and the computing was conducted using Apache Hive on a Hadoop-based big data computing cluster as detailed in [26]. A block group was considered part of the park if a majority of it was contained in the park boundary. The resulting 12-digit block group FIPS IDs for the six parks were: Glacier NP (300290001003, 300359800001), Grand Canyon NP (040050023005, 040050023001, 040159501002, 040050020002), Rocky Mountain NP (080130136022, 080690028031, 080490002012, 080690028012), Yellowstone NP (160439701002, $560399676002,560299653001,30067980600)$, Yosemite NP (060430004001, 060430004002, 060390001031, 061090042001), and Zion NP (490532701001). SafeGraph numbers thus reflect all flows that had a destination to block groups inside a specific park but origins outside the park. In total, we extracted 869,775 and 656,005 OD flows for 2019 and 2020 respectively.

\subsection{Data Analysis and Visualization}

Our first analyses compared monthly visitation in 2019 and 2020 for the NPS and SafeGraph datasets as a means of 'validating' the latter data. It is important to bear in mind, however, that the NPS figures are themselves only estimates and that some of the methods typically used by the NPS to estimate visitation may have been affected by COVID-19. Nonetheless, a strong correlation between the two datasets would be required if the SafeGraph data are to be useful in studying and understanding park visitation. Furthermore, one of the benefits of the SafeGraph data is that they are available at a daily timestep. We were thus able to examine the temporal correspondence between daily patterns of park visitation and management actions taken in response to COVID-19 using 
the daily OD flows extracted from the 2019 and 2020 SafeGraph Social Distancing Metrics data. Finally, we hypothesized that restrictions related to COVID-19 would not only limit overall visitation but would also alter where visitors came from. To explore this hypothesis, we used the SafeGraph data to calculate and map the Visitor Change Rate between 2019 and 2020 at the state-level for each park as: (2020 visitors-2019 visitors)/2019 visitors. The charts were generated using Matplotlib with Python [27], flow maps were generated using Kepler.gl (https: / / kepler.gl/, accessed on 16 August 2021), and state visitation maps were generated using GeoPandas version 0.90.0 with Python (https://geopandas.org/, accessed on 16 August 2021).

\section{Results}

\subsection{Trends in Park Visitation}

Graphs of data from 2019 (Figure 2: blue lines) and 2020 (Figure 2: gold lines) illustrate the impacts of concerns over the spread of COVID-19 on monthly park visitation. In January and February, visitation differed little between the two years, with 2020 even outpacing 2019 at some parks. Beginning in March and April, park visitation diverged between the two years as the spread of the virus in 2020 raised concerns about travel and triggered the President's emergency declaration in early March and the various park closures in late March and early April. At the more southern parks where the tourist season begins earlier (Grand Canyon NP, Yosemite NP, Zion NP), the divergence was driven by a marked decrease in visitation from 2019 to 2020. At the more northern parks (especially Glacier NP and Yellowstone NP), the divergence instead reflected an extended period of low visitation in 2020. Visitation in 2020 then approached or passed that from 2019 by late summer or early autumn at most of the parks as they reopened.

The other notable pattern in the monthly visitation graphs was the high degree of correspondence between values from the NPS (Figure 2: solid lines) and SafeGraph (Figure 2: dashed lines) datasets for both 2019 and 2020. The results of linear regression analyses were very encouraging, with a coefficient of determination $\left(R^{2}\right)$ between the datasets that (1) was greater than 0.92 for both years at Glacier NP, Rocky Mountain NP, and Yellowstone NP; (2) exceeded 0.80 for all parks in 2019; and (3) was only lower than 0.87 at two parks (Grand Canyon NP and Zion NP) in 2020 (Figure 3).

\subsection{COVID-19 Management Responses and Park Visitation}

The correspondence between patterns of monthly park visitation based on NPS and SafeGraph data (Figure 2) coupled with the high correlation between the two datasets (Figure 3) suggests that the OD flows extracted from the SafeGraph dataset provided a good approximation of visitation patterns in 2019 and 2020 for the parks examined in this study. However, the SafeGraph data also permitted a more refined examination of the correspondence between park visitation patterns and management actions because of their daily temporal resolution (Figure 4). Note that park closures and reopenings are indicated in Figure 4 by solid red and green vertical lines, respectively; relevant dates for these events are listed in Table 1. The President's emergency declaration is shown as a gray vertical line on 13 March 2020.

As with the monthly data, there were minimal differences in visitation between 2019 and 2020 for the first two months. At Zion NP and Grand Canyon NP, visitation in 2020 dropped dramatically at the time of the emergency declaration, even before the parks closed at the end of the month. There were similar decreases at Yosemite NP and Rocky Mountain NP, although there was only one week between the emergency declaration and the park closures. At Yellowstone NP and Glacier NP, the emergency declaration and park closings had little immediate effect on visitation because they came before visitation typically increases in late April and May. The closures were, however, coincident with a delay to the start of the tourist season.

At all of the parks, partial and full reopenings in late May and June were followed by increased visitation, with spikes even discernible for holiday weekends associated with 
Independence Day (4 July) and Labor Day (the first Monday in September). Visitation in 2020 reached values comparable to 2019 by late June at Rocky Mountain NP and Zion NP, late July at Yellowstone NP, and September at Glacier NP and Grand Canyon NP. At Yosemite NP, a secondary dip in visitation in September 2020 was caused by closures associated with wildfires; as a result, visitation didn't approach that from 2019 until late October.
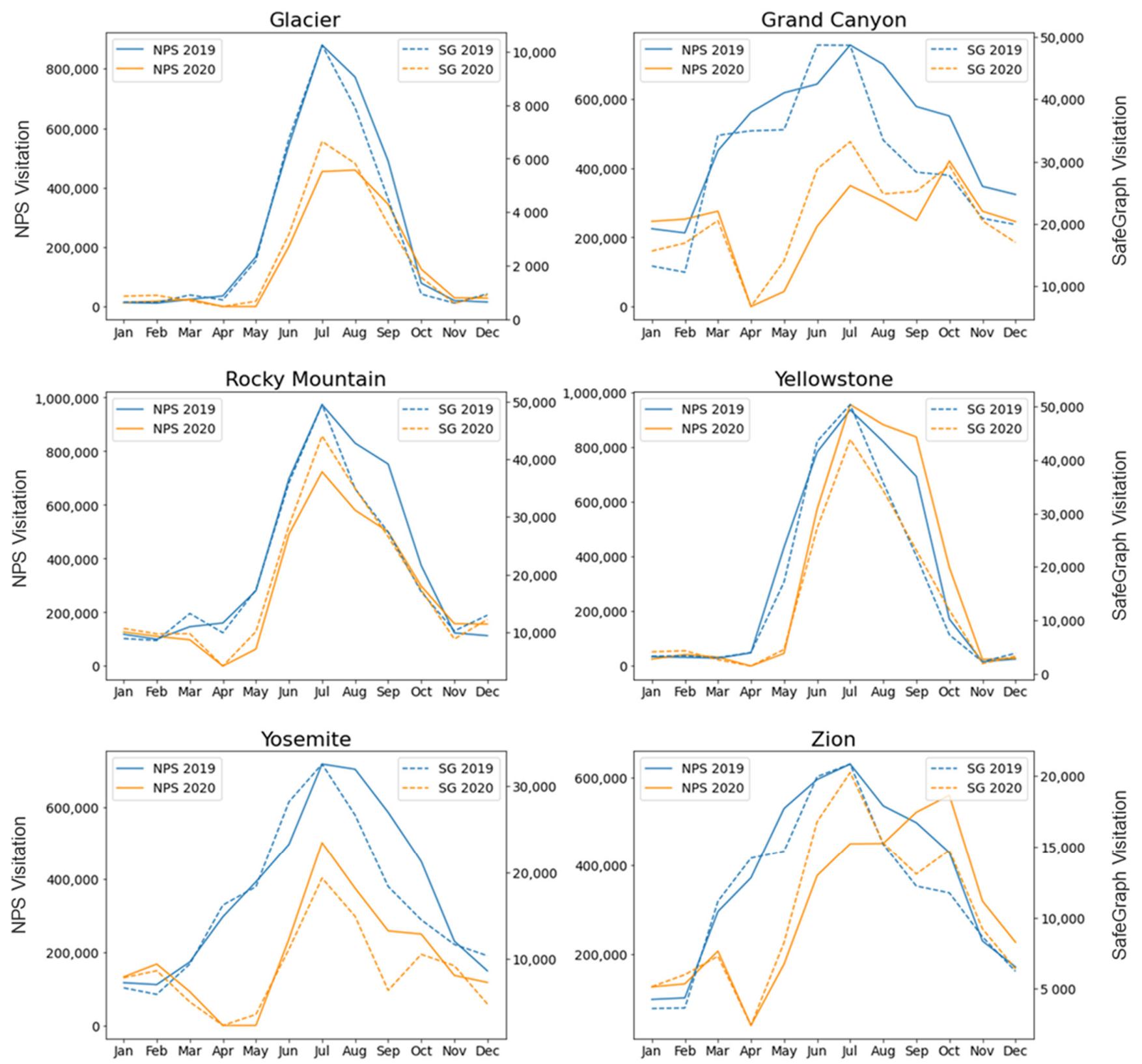

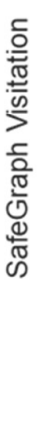

Figure 2. Monthly visitation trends in 2019 (blue lines) and 2020 (gold lines) for six U.S. national parks. Solid lines represent values from the National Park Service Visitor Use Statistics webpage, while dashed lines are values derived from the SafeGraph Social Distancing Metrics dataset. 

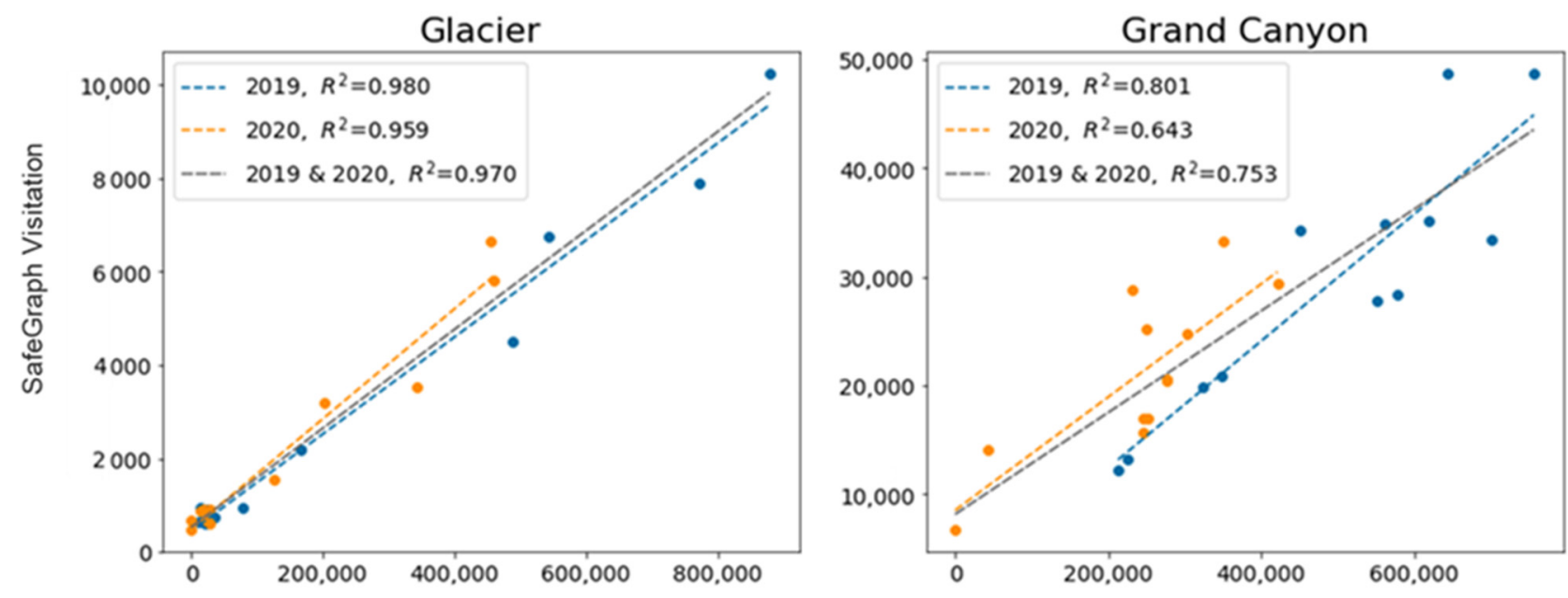

Rocky Mountain
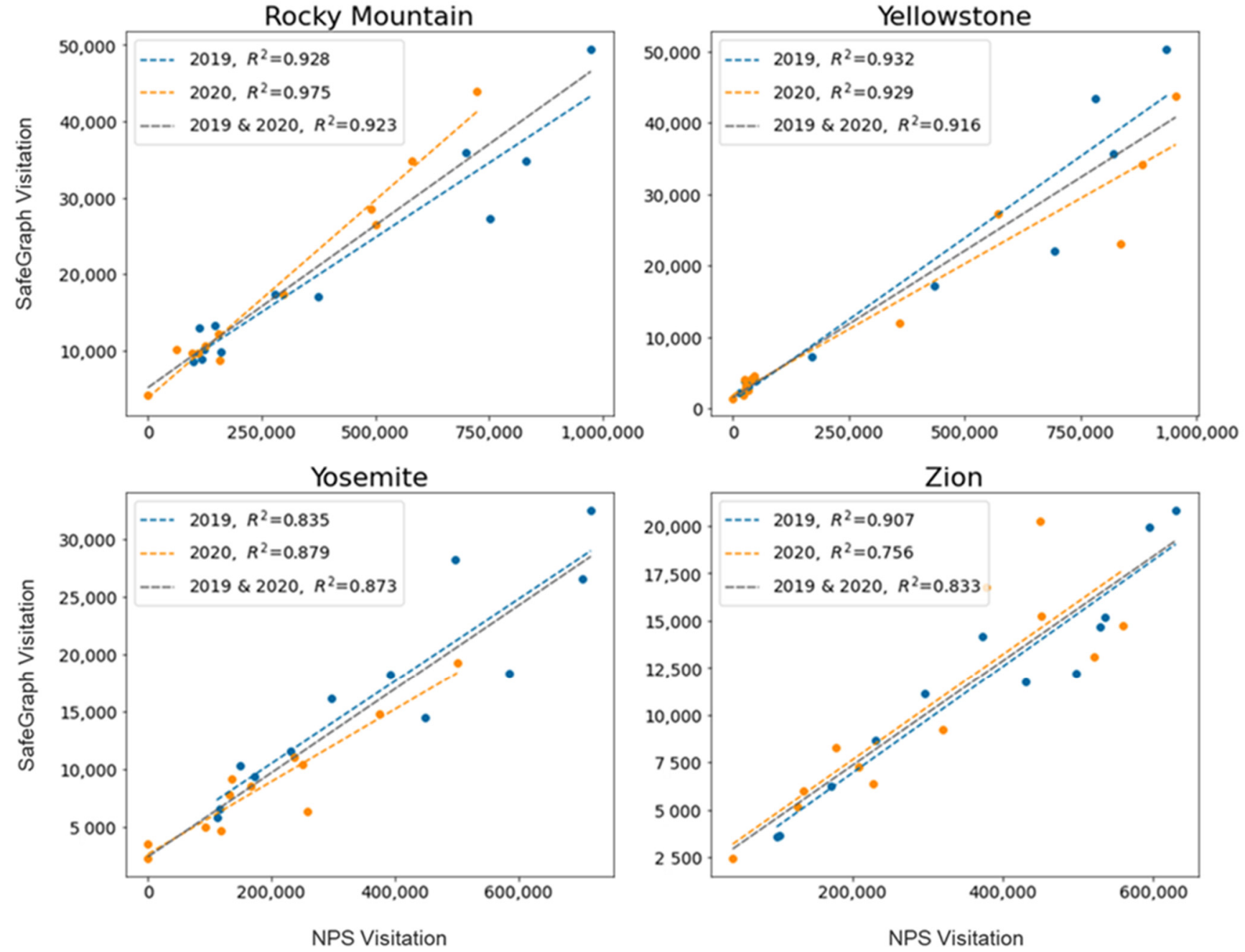

Figure 3. Correlation between monthly visitation estimates (2019 and 2020) of U.S. National Park Service data and values derived from the SafeGraph Social Distancing Metrics dataset. 

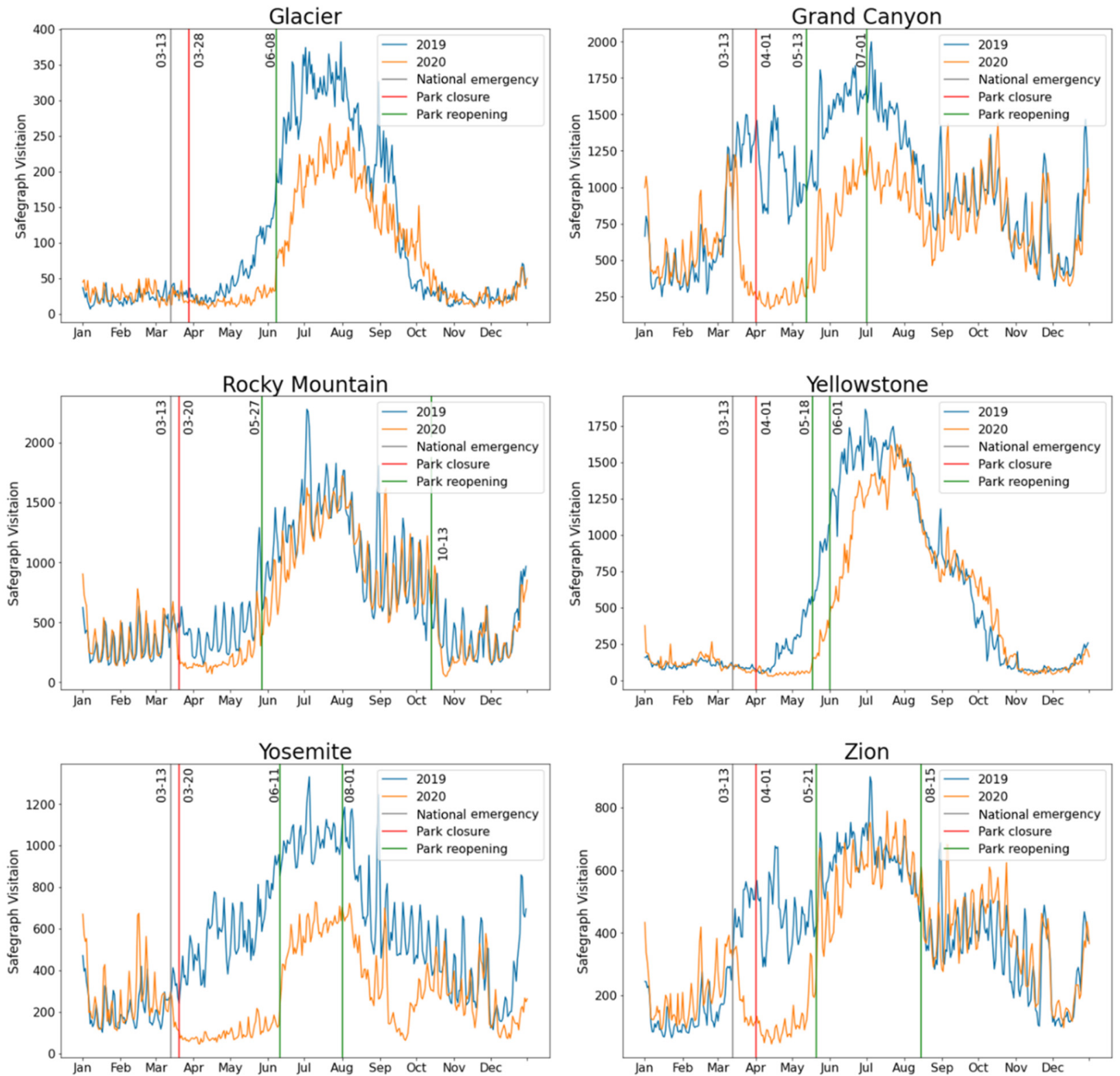

Figure 4. Daily visitation at six U.S. national parks in 2019 (blue) and 2020 (gold) based on data from SafeGraph's Social Distancing Metric dataset. Dates of park closures and openings associated with COVID-19 are shown as vertical lines (Red: park closure; Green: park reopening). The gray vertical line indicates the presidential declaration of emergency.

\subsection{Spatial Patterns of Park Visitation}

In addition to having the benefit of a daily timestep, the SafeGraph data allowed us to track visitation flows to each individual park over time. Mapping these flows provides a compelling method for visualizing the spatial impacts of COVID-19 on national park visitation, for example, by (1) contrasting the differences in visitor number and origins for April in 2019 and 2020, and (2) demonstrating the effects of park reopening between April and October in 2020 (Figure 5).

The OD flows also allowed us to analyze annual changes in the origin of park visitors at the state level from 2019 to 2020 (Figure 6). The most obvious pattern was not surprising: the number of visitors from many states decreased, with the greatest percentage declines noted for states located farthest away from a park (e.g., those in the northeast and midAtlantic). Visitation declines were especially noticeable for Yosemite NP, which had the most stringent restrictions of the six parks coupled with a September park closure caused by a wildfire. Glacier NP also exhibited widespread declines, with the exception of two 
outlier states (Kansas and West Virginia) that had low visitation numbers in both years, making the increases somewhat trivial. Yellowstone NP and Zion NP, on the other hand, experienced steady or even slightly increased visitation in 2020 from multiple states (most prominently those near the park), despite being closed for roughly two months in 2020.
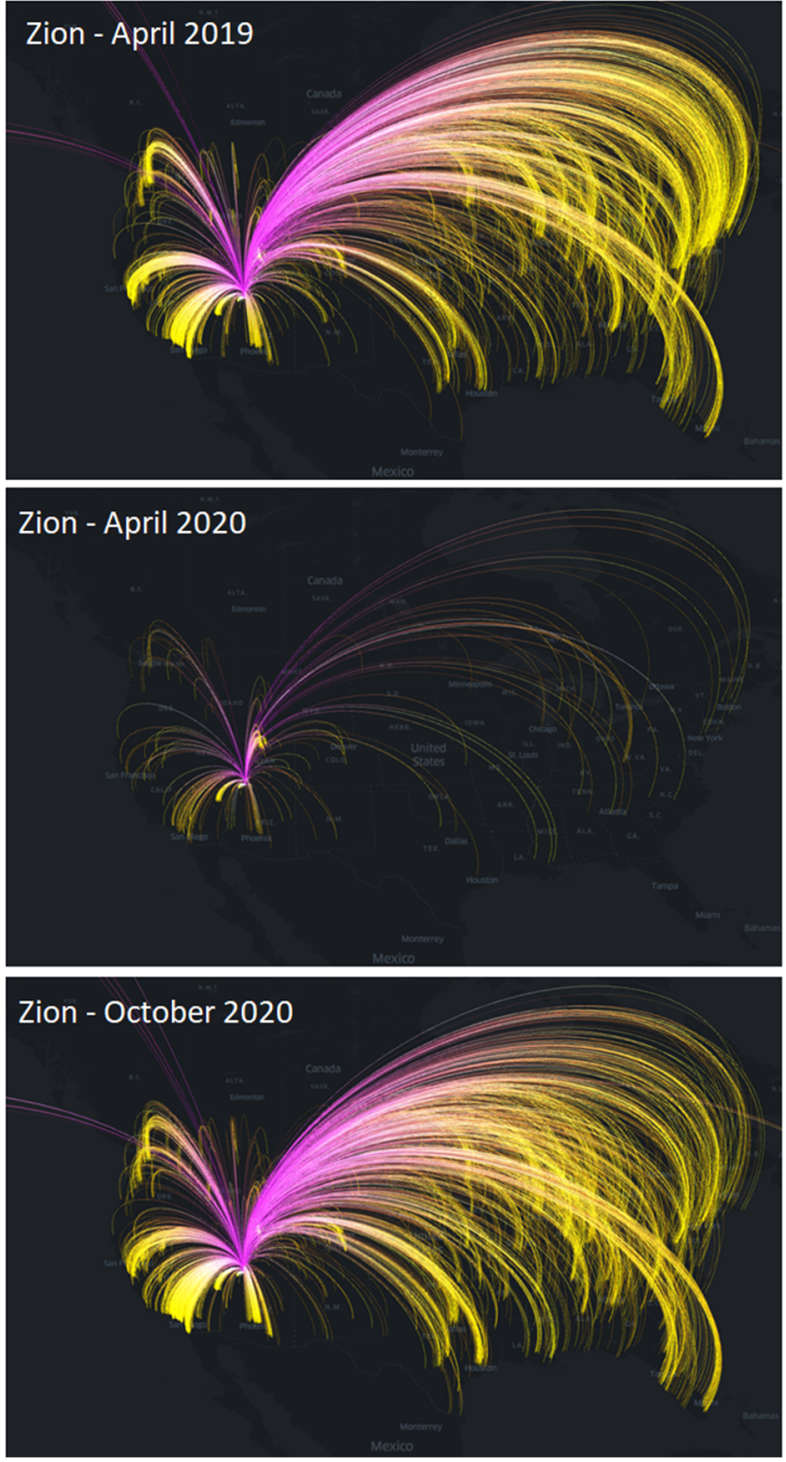
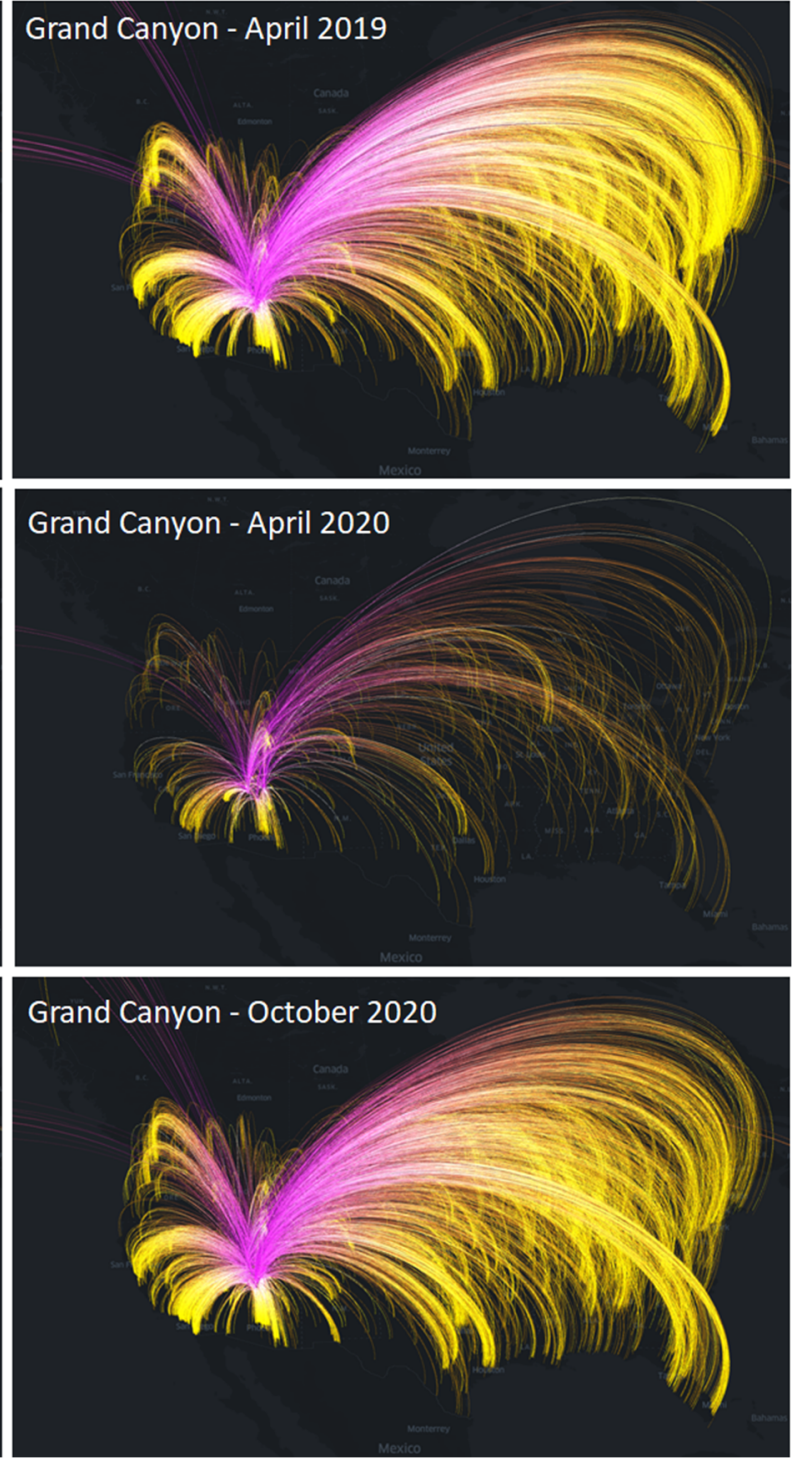

Figure 5. Comparison of visitation flows for three months in 2019 and 2020 at Zion NP and Grand Canyon NP. The maps were generated using Kepler.gl.

Annual analyses of visitor origin provide an incomplete perspective of changing visitation patterns related to COVID-19, however, because they fail to capture changes that took place at finer time scales. At Zion NP, for example, visitation was higher in January and February in 2020 than 2019 (Figure 2), with increased visitorship from states around the country before the imposition of visitor restrictions associated with COVID-19 (Figure 7). When the park reopened in late May and early June, there was an initial surge of visitation from surrounding states (Arizona, Nevada, California), and by August and September, overall visitation had again surpassed that of 2019 (Figure 2), with notable increases in visitors for many states (Figure 7). Yellowstone NP provides a similar example of the rapid rise in visitation as COVID-19 restrictions were eased, with initial increases in visitation over 2019, most notably from Idaho, Utah, and Nevada, but then spreading outward through the rest of the year (Figure 8). 


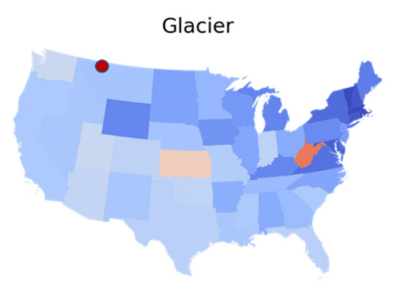

Yellowstone

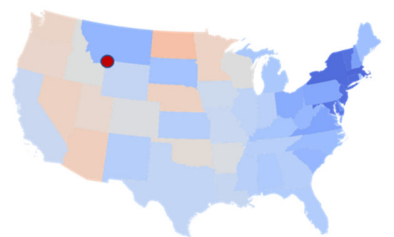

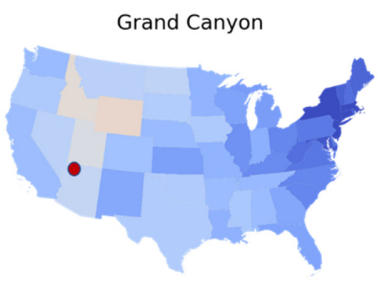

Yosemite

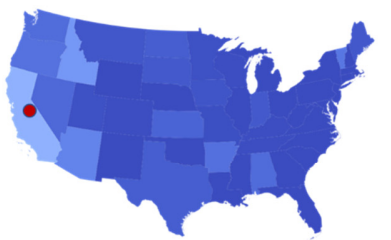

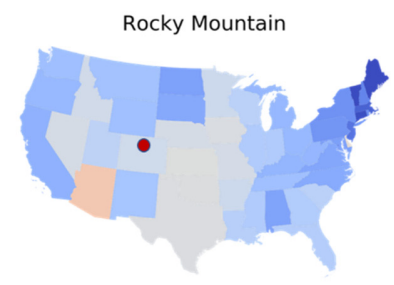

Zion

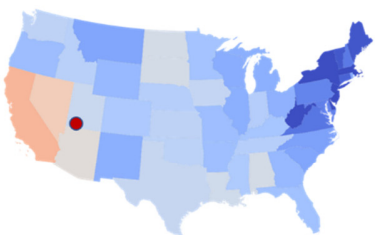

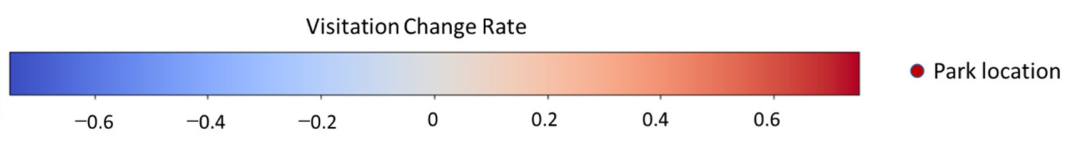

Figure 6. Changes in park visitation between 2019 and 2020 by visitor origin. For each state, change was calculated as: (2020 visitor number-2019 visitor number)/2019 visitor number. The maps were generated using GeoPandas version 0.90 .0 with Python.

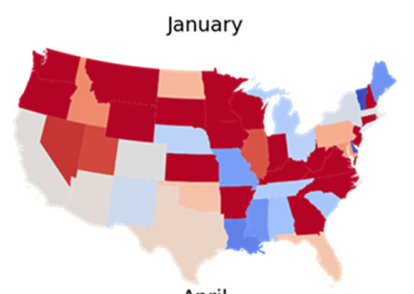

April
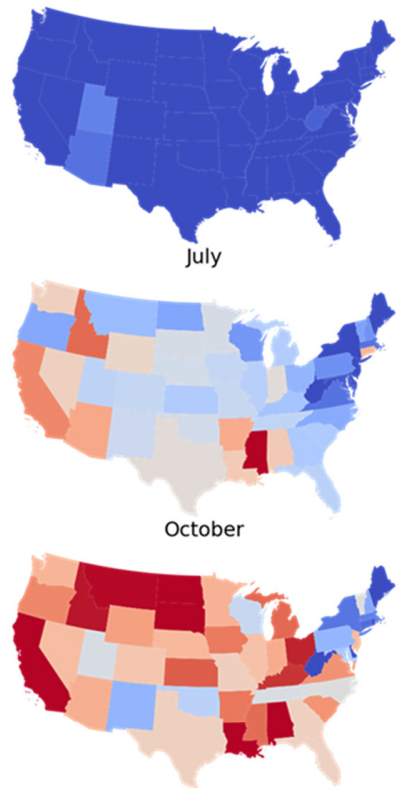

February
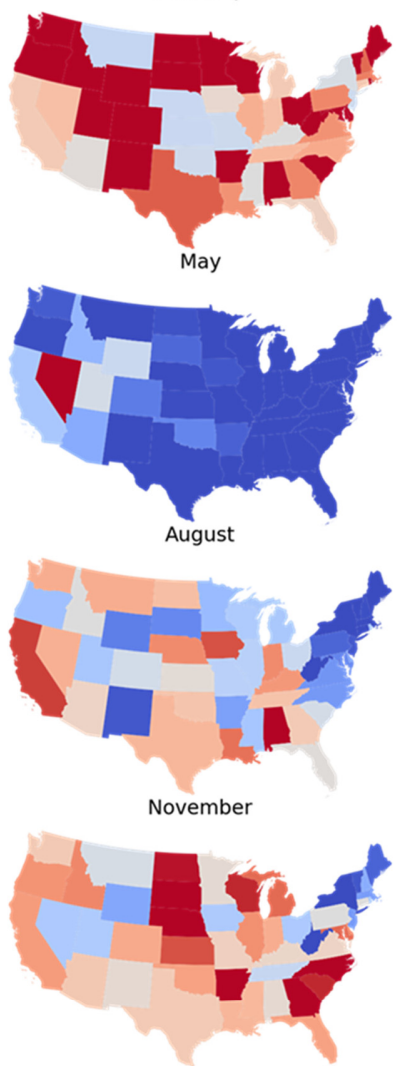
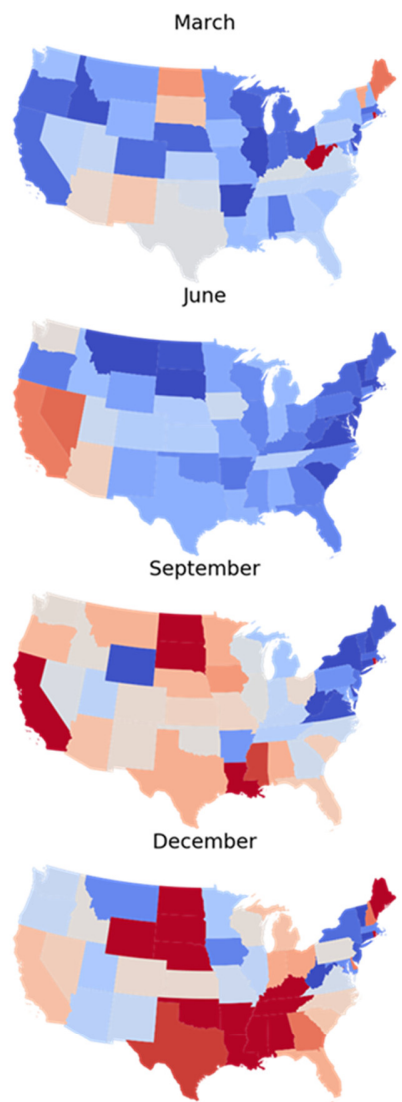

Visitation Change Rate

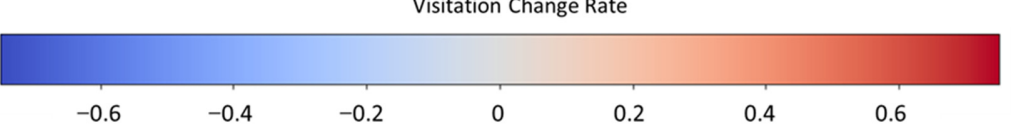

Figure 7. Monthly changes in park visitation at Zion National Park between 2019 and 2020 by visitor origin. For each state, change was calculated as: (2020 visitor number-2019 visitor number)/ 2019 visitor number. The maps were generated using GeoPandas version 0.90 .0 with Python. 

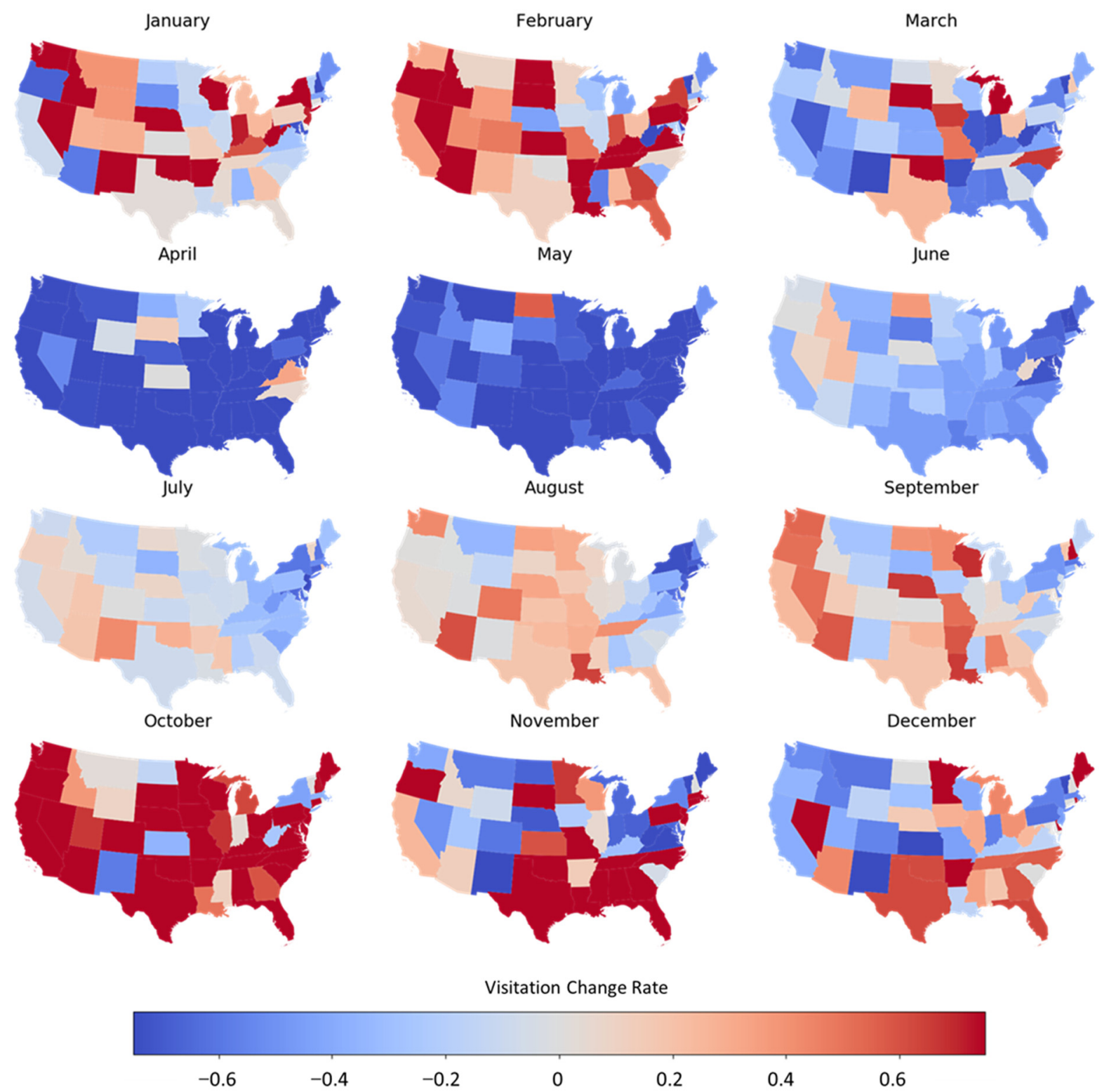

Figure 8. Monthly changes in park visitation at Yellowstone National Park between 2019 and 2020 by visitor origin. For each state, change was calculated as: (2020 visitor number-2019 visitor number)/2019 visitor number. The maps were generated using GeoPandas version 0.90 .0 with Python.

\section{Discussion}

Because of their spatial extent, available long-term data, and value as places for promoting personal well-being, U.S. national parks provide ideal opportunities for examining the impacts of the COVID-19 pandemic on protected areas [28]. Researchers have, for example, been using novel and innovative approaches to examine the effects of COVID-19 on park visitation, including the impacts of social distancing and lockdown measures on public interest in visiting national parks [29], the effects of the pandemic on outdoor recreation trips and values [30], and the potential effects of COVID-19 on local economies in gateway communities [31], among other things. There have also been attempts to use big data to better understand the drivers of park visitation in response to COVID-19, e.g., [16], setting the stage for the work conducted in this study.

Despite closures and an overall $27.6 \%$ decline in NPS visitation in 2020, fifteen national parks set visitation records and others saw monthly records fall as people swarmed to the parks after their reopening [14]. Visitation at the parks examined in this study, as 
captured by both the NPS and SafeGraph datasets, mirrored general patterns for the broader national park system. For our six parks, monthly visitation in 2020 was on pace with, or exceeding, that from 2019 through January and February until concerns arose over the spread of the COVID-19 virus. In conjunction with a presidential declaration of emergency, rising public health concerns, COVID-related travel restrictions, stay-at-home orders, and border closures, park and facility closures resulted in dramatic decreases in visitor number beginning in March and continuing through April and into May (and in some places, longer) (Table 1; Figures 2 and 4). As the virus spread, the need for access to parks and other protected areas that provide outdoor recreation was recognized and touted [13,32], and national parks began to reopen, with safety protocols (e.g., educational signage, masking, social distancing, reduced shuttle capacity, restricted park and trail access, and limited capacities at campgrounds and lodgings) implemented as needed. Visitation then rose, sometimes very rapidly (Figure 4), eventually reaching and even surpassing that from 2019 at several of the parks as people sought accessible, high-quality recreational outlets.

While basic trends in national park visitation related to COVID-19 were readily apparent in the monthly NPS visitation estimates, the SafeGraph data provided greater temporal resolution and additional spatial information, affording a more nuanced view of changing visitation patterns. The visitor flow maps, for example, not only demonstrated how the pandemic impacted the number of park visitors, but also provided a spatial perspective to visitation changes in response to COVID-19. With travel restrictions often still in place and ongoing concerns about long-distance air travel, parks initially saw the greatest increases in visitorship (compared to 2019 levels) coming from nearby states (Figures 6-8). The 'visitorshed' expanded later as people from a broader range of states travelled to the parks (Figures 7 and 8 ).

We want to stress that the methods used in this study are meant only to complement, not replace, existing methods for estimating park visitation. They do, however, offer some additional advantages. Current methods for estimating visitation are inconsistent across parks and often rely on vehicle multipliers, regression formulas, and other 'indirect' procedures [33]. In contrast, the methods used to collect and extract the SafeGraph visitation data were consistent across the six parks and through time. We were, nonetheless, especially encouraged by the strong correlation between the SafeGraph-derived monthly visitation numbers and statistics from the NPS (Figure 3), indicating that SafeGraph-derived park visitation flows could be compatible with NPS estimates.

There are, however, some limitations to the SafeGraph data that warrant future exploration. It can be difficult to completely separate park visitors from other flows (e.g., local residents) at the census block group level because some block groups are not fully contained by a park. This helps to explain why visitation sometimes exceeded zero even when a park was closed (Figure 4) and could be a greater issue for smaller or more urban parks than those examined here. Second, the SafeGraph data used in this study only cover flows within the U.S. and thus ignore international travelers, who can make up a significant percentage of visitors at some parks during certain seasons (e.g., 17\% at Yellowstone NP [34]). To bridge this gap, social media data, such as geotagged tweets, that have been proven to be effective in tracking global human movement [35-37] can be incorporated in future studies.

\section{Conclusions}

U.S. national parks protect the best of our country's natural heritage, serve as important economic engines (both locally and nationally), and provide vital places for recreation and personal restoration. Many of the most pressing challenges to protecting those values while providing for the enjoyment of park scenery, features, and wildlife in a manner that will leave them unimpaired for future generations center on managing park visitation. Specifically, effective long-term park planning and management require timely and rele- 
vant information on the numbers, use, characteristics, and behaviors of people who are in the parks.

This study was exploratory and retrospective in nature, focusing narrowly on responses to the COVID-19 pandemic. With COVID-19 restrictions easing further in 2021, all-time monthly visitation records have already been set at a number of national parks, including some highlighted in this paper [38]. This surge in visitation due to 'pandemic fatigue' is posing management challenges [39] and generating debate over restricting park access and the implementation of reservation systems at some high-profile parks [40]. Our results demonstrate that approaches exploiting data collected anonymously from mobile devices can provide useful information on patterns and drivers of park visitation as park managers continue to assess the impacts of COVID-19 on their respective units.

More broadly, however, the NPS relies on visitor statistics to avoid potential user conflicts with, or damage to, biological, physical, cultural, and historical resources within parks and to more effectively allocate funding and staff to individual park activities and projects [41]. Data on not just visitor numbers but also visitor origins and movements, (such as those provided in this study) are also valuable for regional planners, business leaders, transportation authorities, and NPS managers and social scientists seeking to better evaluate a park's economic linkages to neighboring areas [33]. Finally, we contend that our approach may be valuable for addressing new questions in novel ways. For example, because the SafeGraph data are aggregated to census block groups, our methodology could be used to explore patterns of differential park access and equity, a topic of great interest to the NPS. In short, we posit that cellphone-based big mobility data with fine temporal resolution and rich spatial information can afford a more nuanced view of changing patterns of park visitation that complements (and in some ways, transcends) existing methods for quantifying park visitation, highlighting the capability of big mobility data to provide rapid knowledge of human movement with fine spatiotemporal granularity.

Author Contributions: Conceptualization, J.A.K. and Z.L.; Data curation, Z.L.; Formal analysis, Z.L., H.N. and X.H.; Funding acquisition, J.A.K. and Z.L.; Investigation, J.A.K., Z.L., H.N. and X.H.; Methodology, J.A.K., Z.L., H.N. and X.H.; Project administration, J.A.K. and Z.L.; Resources, J.A.K. and Z.L.; Software, Z.L.; Supervision, J.A.K. and Z.L.; Validation, J.A.K., Z.L., H.N. and X.H.; Visualization, J.A.K., Z.L. and H.N.; Writing-Original draft, J.A.K., Z.L. and X.H.; Writing-Review and editing, J.A.K. and Z.L. All authors have read and agreed to the published version of the manuscript.

Funding: This research and the associated article processing charges were funded by University of South Carolina ASPIRE program grant number 135400-20-53382.

Institutional Review Board Statement: Not applicable.

Informed Consent Statement: Not applicable.

Data Availability Statement: The Social Distancing Metrics data can be obtained from SafeGraph (https:/ / www.safegraph.com/, accessed on 16 August 2021). The raw data of extracted origindestination flows for each park will be provided upon request.

Acknowledgments: The authors wish to thank Zahida Ashroff and Meghan Teumer for their assistance in data collection and preparation and three anonymous reviewers for their comments on an earlier draft of this paper.

Conflicts of Interest: The authors declare no conflict of interest.

\section{References}

1. International Union for Conservation of Nature. Conserving Nature in a Time of Crisis: Protected Areas and COVID-19. Available online: https:/ / www.iucn.org/news/world-commission-protected-areas /202005/conserving-nature-a-time-crisis-protectedareas-and-covid-19 (accessed on 2 July 2021).

2. Smith, M.K.S.; Smit, I.P.J.; Swemmer, L.K.; Mokhatla, M.M.; Freitag, S.; Roux, D.J.; Dziba, L. Sustainability of Protected Areas: Vulnerabilities and Opportunities as Revealed by COVID-19 in a National Park Management Agency. Biol. Conserv. 2021, 255, 108985. [CrossRef] 
3. Spenceley, A.; McCool, S.; Newsome, D.; Báez, A.; Barborak, J.R.; Blye, C.-J.; Bricker, K.; Sigit Cahyadi, H.; Corrigan, K.; Halpenny, E.; et al. Tourism in Protected and Conserved Areas amid the COVID-19 Pandemic. PARKS 2021, 27, 103-118. [CrossRef]

4. Corlett, R.T.; Primack, R.B.; Devictor, V.; Maas, B.; Goswami, V.R.; Bates, A.E.; Koh, L.P.; Regan, T.J.; Loyola, R.; Pakeman, R.J.; et al. Impacts of the Coronavirus Pandemic on Biodiversity Conservation. Biol. Conserv. 2020, 246, 108571. [CrossRef] [PubMed]

5. Miller, J. “We've Never Seen This": Wildlife Thrives in Closed US National Parks. Available online: http:/ / www.theguardian. com/environment/2020/may/21/wildlife-national-parks-covid-19-shutdown-death-valley (accessed on 1 July 2021).

6. Greenfield, P.; Muiruri, P. Conservation in Crisis: Ecotourism Collapse Threatens Communities and Wildlife. Available online: http:/ / www.theguardian.com/environment/2020/may/05/conservation-in-crisis-covid-19-coronavirus-ecotourismcollapse-threatens-communities-and-wildlife-aoe (accessed on 1 July 2021).

7. Rutz, C.; Loretto, M.-C.; Bates, A.E.; Davidson, S.C.; Duarte, C.M.; Jetz, W.; Johnson, M.; Kato, A.; Kays, R.; Mueller, T.; et al. COVID-19 Lockdown Allows Researchers to Quantify the Effects of Human Activity on Wildlife. Nat. Ecol. Evol. 2020, 4, 1156-1159. [CrossRef] [PubMed]

8. Kaplan, S. The Restorative Benefits of Nature: Toward an Integrative Framework. J. Environ. Psychol. 1995, 15, 169-182. [CrossRef]

9. Samuelsson, K.; Barthel, S.; Colding, J.; Macassa, G.; Giusti, M. Urban Nature as a Source of Resilience during Social Distancing amidst the Coronavirus Pandemic. OSF Prepr. 2020. [CrossRef]

10. Waithaka, J.; Dudley, N.; Álvarez, M.; Arguedas Mora, S.; Chapman, S.; Figgis, P.; Fitzsimons, J.; Gallon, S.; Gray, T.N.E.; Kim, M.; et al. Impacts of COVID-19 on Protected and Conserved Areas: A Global Overview and Regional Perspectives. PARKS 2021, 27, 41-56. [CrossRef]

11. Miller-Rushing, A.J.; Athearn, N.; Blackford, T.; Brigham, C.; Cohen, L.; Cole-Will, R.; Edgar, T.; Ellwood, E.R.; Fisichelli, N.; Pritz, C.F.; et al. COVID-19 Pandemic Impacts on Conservation Research, Management, and Public Engagement in US National Parks. Biol. Conserv. 2021, 257, 109038. [CrossRef]

12. National Park Service Visitor Spending Generates Economic Impact of More Than $\$ 41$ Billion (National Park Service, Office of Communications). Available online: https:/ /www.nps.gov/orgs/1207/06-11-20-nps-visitor-spending-generates-economicimpact-of-more-than-41-billion.htm (accessed on 6 June 2021).

13. National Parks Hosted 237 Million Visitors in 2020 (National Park Service, Office of Communications). Available online: https:/ / www.nps.gov / orgs/1207/02-25-21-national-parks-hosted-237-million-visitors-in-2020.htm (accessed on 6 June 2021).

14. Ziesler, P.; Spalding, C. Statistical Abstract: 2020; National Park Service: Fort Collins, CO, USA, 2021.

15. Tenkanen, H.; Di Minin, E.; Heikinheimo, V.; Hausmann, A.; Herbst, M.; Kajala, L.; Toivonen, T. Instagram, Flickr, or Twitter: Assessing the Usability of Social Media Data for Visitor Monitoring in Protected Areas. Sci. Rep. 2017, 7, 17615. [CrossRef]

16. Rice, W.L.; Pan, B. Understanding Changes in Park Visitation during the COVID-19 Pandemic: A Spatial Application of Big Data. Wellbeing Space Soc. 2021, 2, 100037. [CrossRef]

17. Wood, S.A.; Guerry, A.D.; Silver, J.M.; Lacayo, M. Using Social Media to Quantify Nature-Based Tourism and Recreation. Sci. Rep. 2013, 3, 2976. [CrossRef]

18. Sessions, C.; Wood, S.A.; Rabotyagov, S.; Fisher, D.M. Measuring Recreational Visitation at U.S. National Parks with CrowdSourced Photographs. J. Environ. Manag. 2016, 183, 703-711. [CrossRef]

19. Fisher, D.M.; Wood, S.A.; White, E.M.; Blahna, D.J.; Lange, S.; Weinberg, A.; Tomco, M.; Lia, E. Recreational Use in Dispersed Public Lands Measured Using Social Media Data and On-Site Counts. J. Environ. Manag. 2018, 222, 465-474. [CrossRef]

20. Volenec, Z.M.; Abraham, J.O.; Becker, A.D.; Dobson, A.P. Public Parks and the Pandemic: How Park Usage Has Been Affected by COVID-19 Policies. PLoS ONE 2021, 16, e0251799. [CrossRef]

21. Hamstead, Z.A.; Fisher, D.; Ilieva, R.T.; Wood, S.A.; McPhearson, T.; Kremer, P. Geolocated Social Media as a Rapid Indicator of Park Visitation and Equitable Park Access. Comput. Environ. Urban Syst. 2018, 72, 38-50. [CrossRef]

22. Zhou, C.; Fu, L.; Xue, Y.; Wang, Z.; Zhang, Y. Using Multi-Source Data to Understand the Factors Affecting Mini-Park Visitation in Yancheng. Environ. Plan B Urban Anal. City Sci. 2021. [CrossRef]

23. Juhász, L.; Hochmair, H. Studying Spatial and Temporal Visitation Patterns of Points of Interest Using SafeGraph Data in Florida. J. Geogr. Inf. Sci. 2020, 8, 119-136. [CrossRef]

24. Welcome to Visitor Use Statistics (National Park Service). Available online: https://irma.nps.gov/STATS/ (accessed on 2 July 2021).

25. SafeGraph, Social Distancing Metrics. 2021. Available online: https://docs.safegraph.com/docs/social-distancing-metrics (accessed on 29 July 2021).

26. Li, Z.; Huang, X.; Ye, X.; Li, X. ODT Flow Explorer: Extract, Query, and Visualize Human Mobility. PLoS ONE 2021, in press.

27. Hunter, J.D. Matplotlib: A 2D graphics environment. Comput. Sci. Eng. 2007, 9, 90-95. [CrossRef]

28. Jacobs, L.A.; Blacketer, M.P.; Peterson, B.A.; Levithan, E.; Russell, Z.A.; Brunson, M. Responding to COVID-19 and Future Times of Uncertainty: Challenges and Opportunities Associated with Visitor Use, Management, and Research in Parks and Protected Areas. Parks Steward. Forum 2020, 36, 483-488. [CrossRef]

29. Souza, C.N.; Rodrigues, A.C.; Correia, R.A.; Normande, I.C.; Costa, H.C.M.; Guedes-Santos, J.; Malhado, A.C.M.; Carvalho, A.R.; Ladle, R.J. No Visit, No Interest: How COVID-19 Has Affected Public Interest in World's National Parks. Biol. Conserv. 2021, 256, 109015. [CrossRef]

30. Landry, C.E.; Bergstrom, J.; Salazar, J.; Turner, D. How Has the COVID-19 Pandemic Affected Outdoor Recreation in the U.S.? A Revealed Preference Approach. Appl. Econ. Perspect. Policy 2021, 43, 443-457. [CrossRef] 
31. Templeton, A.J.; Goonan, K.; Fyall, A. COVID-19 and Its Impact on Visitation and Management at US National Parks. Int. Hosp. Rev. 2021. [CrossRef]

32. Slater, S.J.; Christiana, R.W.; Gustat, J. Recommendations for Keeping Parks and Green Space Accessible for Mental and Physical Health during COVID-19 and Other Pandemics. Prev. Chronic Dis. 2020, 17, E59. [CrossRef] [PubMed]

33. Brulliard, N. Who Counts? A Closer Look at Parks' Record Visitation Numbers. Available online: https://www.npca.org/ articles /1146-who-counts-a-closer-look-at-parks-record-visitation-numbers (accessed on 28 July 2021).

34. Yellowstone Releases Reports about Visitors and Traffic (National Park Service). Available online: https://www.nps.gov/yell/ learn/news/17042.htm (accessed on 2 July 2021).

35. Hawelka, B.; Sitko, I.; Beinat, E.; Sobolevsky, S.; Kazakopoulos, P.; Ratti, C. Geo-Located Twitter as Proxy for Global Mobility Patterns. Cartogr. Geogr. Inf. Sci. 2014, 41, 260-271. [CrossRef]

36. Huang, X.; Li, Z.; Jiang, Y.; Li, X.; Porter, D. Twitter Reveals Human Mobility Dynamics during the COVID-19 Pandemic. PLoS ONE 2020, 15, e0241957. [CrossRef]

37. Li, Z.; Huang, X.; Ye, X.; Jiang, Y.; Martin, Y.; Ning, H.; Hodgson, M.E.; Li, X. Measuring Global Multi-Scale Place Connectivity Using Geotagged Social Media Data. arXiv 2021, arXiv:2102.03991.

38. Pohle, A. National Parks Are Overcrowded and Closing Their Gates. Available online: https://www.wsj.com/articles/nationalparks-are-overcrowded-and-closing-their-gates-11623582002 (accessed on 2 July 2021).

39. Graziosi, G. National Parks Inundated with Trash as Visitor Numbers Spike after Lockdowns. Available online: https://www. independent.co.uk/news/world/americas/national-parks-trash-visitors-pandemic-b1870857.html (accessed on 1 July 2021).

40. Childers, M. Overcrowded US National Parks Need a Reservation System. The Conversation. 2021. Available online: http: / / theconversation.com/overcrowded-us-national-parks-need-a-reservation-system-158864 (accessed on 26 June 2021).

41. Understanding Park Visitor Characteristics (National Park Service). Available online: https://www.nps.gov/articles/denalipark-visitors.htm. (accessed on 27 July 2021). 